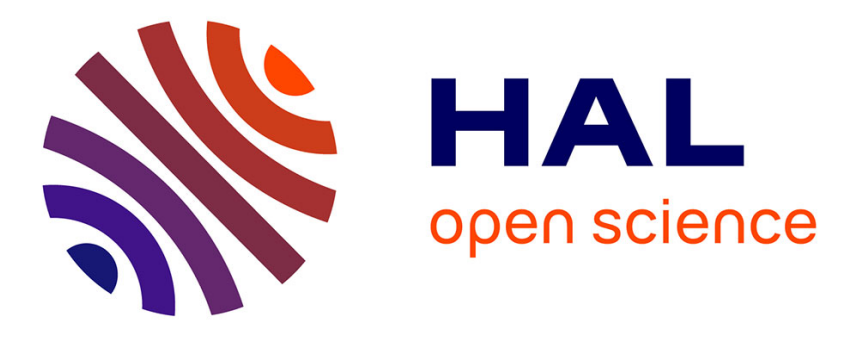

\title{
Active surveillance of bat rabies in France: a 5-year study (2004-2009)
}

Evelyne Picard-Meyer, Marie-Jo Dubourg-Savage, Laurent Arthur, Michel

Barataud, David Bécu, Sandrine Bracco, Christophe Borel, Gérald Larcher, Benjamin Meme-Lafond, Marie Moinet, et al.

\section{To cite this version:}

Evelyne Picard-Meyer, Marie-Jo Dubourg-Savage, Laurent Arthur, Michel Barataud, David Bécu, et al. Active surveillance of bat rabies in France: a 5-year study (2004-2009). Veterinary Microbiology, 2011, 151 (3-4), pp.390. 10.1016/j.vetmic.2011.03.034 . hal-00717082

\section{HAL Id: hal-00717082 \\ https://hal.science/hal-00717082}

Submitted on 12 Jul 2012

HAL is a multi-disciplinary open access archive for the deposit and dissemination of scientific research documents, whether they are published or not. The documents may come from teaching and research institutions in France or abroad, or from public or private research centers.
L'archive ouverte pluridisciplinaire HAL, est destinée au dépôt et à la diffusion de documents scientifiques de niveau recherche, publiés ou non, émanant des établissements d'enseignement et de recherche français ou étrangers, des laboratoires publics ou privés. 


\section{Accepted Manuscript}

Title: Active surveillance of bat rabies in France: a 5-year study (2004-2009)

Authors: Evelyne Picard-Meyer, Marie-Jo Dubourg-Savage, Laurent Arthur, Michel Barataud, David Bécu, Sandrine

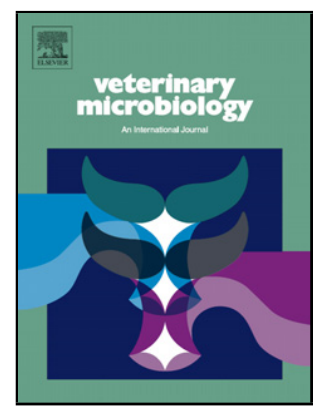
Bracco, Christophe Borel, Gérald Larcher, Benjamin Meme-Lafond, Marie Moinet, Emmanuelle Robardet, Marine Wasniewski, Florence Cliquet

PII: S0378-1135(11)00208-2

DOI: doi:10.1016/j.vetmic.2011.03.034

Reference: VETMIC 5257

To appear in: $\quad$ VETMIC

Received date: $\quad 31-7-2010$

Revised date: $\quad$ 17-3-2011

Accepted date: $\quad 31-3-2011$

Please cite this article as: Picard-Meyer, E., Dubourg-Savage, M.-J., Arthur, L., Barataud, M., Bécu, D., Bracco, S., Borel, C., Larcher, G., Meme-Lafond, B., Moinet, M., Robardet, E., Wasniewski, M., Cliquet, F., Active surveillance of bat rabies in France: a 5-year study (2004-2009), Veterinary Microbiology (2010), doi:10.1016/j.vetmic.2011.03.034

This is a PDF file of an unedited manuscript that has been accepted for publication. As a service to our customers we are providing this early version of the manuscript. The manuscript will undergo copyediting, typesetting, and review of the resulting proof before it is published in its final form. Please note that during the production process errors may be discovered which could affect the content, and all legal disclaimers that apply to the journal pertain. 


\section{Active surveillance of bat rabies in France: a 5-year study (2004-2009)}

Evelyne Picard-Meyer ${ }^{1}$, Marie-Jo Dubourg-Savage ${ }^{2}$, Laurent Arthur², Michel Barataud², David Bécu$^{2}$, Sandrine Bracco ${ }^{2}$, Christophe Borel ${ }^{2}$, Gérald Larcher ${ }^{2}$, Benjamin Meme-Lafond ${ }^{2}$, Marie Moinet $^{1}$, Emmanuelle Robardet ${ }^{1}$, Marine Wasniewski ${ }^{1}$, Florence Cliquet $^{1}$

1. Anses Nancy Laboratory for Rabies and Wildlife, French Agency for Food, Environmental and Occupational Health and Safety, Technopole Agricole et Vétérinaire, BP 40 009, 54220 Malzeville, France

Tel.: +33 (0) 3832989 50; fax: +33 (0) 3832989 58; e-mail address: evelyne.picard-meyer@anses.fr

2. SFEPM Chiroptera group, Muséum d'Histoire Naturelle de Bourges, Parc Saint Paul, 18000 Bourges, France

Corresponding author: Evelyne Picard-Meyer

\section{Abstract}

Active surveillance of bats in France started in 2004 with an analysis of 18 of the 45 bat species reported in Europe. Rabies antibodies were detected in six indigenous species, mainly in Eptesicus serotinus and Myotis myotis, suggesting previous contact with the EBLV-1 rabies virus. Nineteen of the 177 tested bats were shown serologically positive in seven sites, particularly in central and south-western France. Neither infectious viral particles nor viral genomes were detected in 173 and 308 tested oral swabs, respectively. The presence of neutralising antibodies in female bats (18.6\%) was significantly higher than in males $(5.6 \%)$.

Key words: Rabies, Lyssavirus, Bat, epidemiological surveillance, France

Abbreviations: BHK-21: Baby hamster kidney cells; EBLV: European bat lyssavirus; RTCIT: rabies tissue culture infection test; FAVNt: fluorescent antibody virus neutralisation test; hnRTPCR: hemi-nested reverse-transcription polymerase chain reaction; $\mathrm{TCID}_{50}$ : median tissue culture infective dose; $95 \% \mathrm{Cl}$ : $95 \%$ confidence interval.

\section{Introduction}

Rabies is a viral zoonosis that causes progressive and ultimately fatal encephalitis. Rabies is a very old disease and is responsible for approximately 55000 human deaths per year worldwide (World Health Organisation, 2008). The rabies virus belongs to genus Lyssavirus, family Rhabdoviridae and can infect all mammals. The virus is usually transmitted through saliva in a bite from an infected animal. 
The Lyssavirus genus includes 11 different recognised species (Bourhy et al., 1993; Carstens, 2010), also referred to as genotypes: "classical" rabies virus (RABV), Lagos bat virus (LBV), Mokola virus (MOKV), Duvenhage virus (DUVV), Australian bat lyssavirus (ABLV), European bat lyssavirus type 1 (EBLV-1) and European bat lyssavirus type 2 (EBLV-2). Four additional bat viruses (the Irkut, West Caucasian bat, Khujand and Aravan viruses) were recently ratified by the International Committee on Virus Taxonomy (Carstens, 2010). Ten of the 11 above-listed recognised virus species have been isolated from bats; only MOKV has not been isolated from bats (Sabeta et al., 2007).

Since the first case of bat rabies found in 1954, approximately 850 cases of rabid bats infected by EBLV-1 (also known as genotype 5 with two variants EBLV-1a and EBLV-1b) or EBLV-2 (genotype 6) have been reported in Europe (Muller et al., 2007). Most cases of bat rabies have been reported in European countries having a well-established rabies surveillance network (Germany, the Netherlands, Denmark, France and Great Britain). EBLV-1 seems to be adapted to E. serotinus (Van der Poel et al., 2000), species in which more than $95 \%$ of cases have been reported, while EBLV-2 appears to infect only Myotis bat species ( $M$. daubentonii and $M$. dasycneme) with 20 cases, of which 10 have been reported in $M$. daubentonii in England (Banyard et al., 2009; Harris et al., 2009). Recently, another species (E. isabellinus) sibling species of $E$. serotinus and mainly found in Southern lberia was shown to be infected with EBLV-1 (Vazquez-Moron et al., 2008b) and sporadic rabies cases have been found in Pipistrellus pipistrellus, Pipistrellus nathusii, Plecotus auritus, Nyctalus noctula (Muller et al., 2007) and Vespertilio murinus (Selimov et al., 1991).

National (Moutou et al., 2003) and European recommendations (Cliquet et al., 2010; Med Vet Net Working Group, 2005) encourage the continuation and reinforcement of bat rabies research and epidemiological surveillance.

60 Here, we report results from field studies carried out in France since 2004 in close collaboration with bat specialists, preventively vaccinated against rabies. The purpose of the present study was to investigate the circulation of EBLV-1 among indigenous bat species and identify species involved in the transmission of bat rabies. The seroprevalence of EBLV-1 was investigated in bats from 2004 to 2009 to improve current knowledge on the epidemiology of bats infected by EBLV-1.

\section{Materials and Methods}

\section{Sampling}

70 From 2004 to 2009,308 bats belonging to 18 species were captured at 18 sites located around 71 the country (Figure 1). Surveillance was undertaken in several regions chosen for their proximity 
to confirmed cases of EBLV-1 infection in E. serotinus (Limousin, Centre, ChampagneArdennes, Lorraine, Midi-Pyrenees and Pays de la Loire). Bats were captured at night in roosts, along commuting routes, at swarming sites or in parturition roosts when the bats left to forage. Bat specialists identified bats to the species level using morphological criteria (Dietz and Von Helversen, 2004; Schober and Grimmberger, 1991). Several parameters were recorded for each bat: sex, reproductive status, age, body weight, forearm length, behaviour and parasite load.

Oral swabs were taken to collect saliva from each trapped bat and stored in $1 \mathrm{~mL}$ of RNAlater (Ambion, France), a buffer solution designed for RNA preservation, for subsequent hemi-nested reverse-transcription PCR ( $h n R T-P C R)$ ( $n=308$ samples) and/or in a volume of $0.3 \mathrm{~mL}$ of DMEM culture (Dulbecco's minimum essential medium, Invitrogen, France) $(n=173)$ for the rabies tissue culture infection test (RTCIT). Blood samples were taken from 185 bats for a modified fluorescent antibody virus neutralisation test (mFAVNt) on EBLV-1. After sampling, all bats were released at the site of capture at night. Capture, handling and sampling were undertaken with authorisation from the French Ministry of the Environment. Bat species, study sites and the number of collected blood and saliva samples are detailed in Table 1.

\section{Laboratory methods}

Oral swabs stored in $0.3 \mathrm{~mL}$ of culture medium $(n=173)$ were analysed using RTCIT on murine neuroblastoma cells (ATCC:CCL31) (Barrat et al., 1988) and by RT-PCR (Picard-Meyer et al., 2004). The 135 oral swabs stored in RNAlater were tested only for the presence of EBLV-1 RNA by hnRT-PCR using universal primers (JW12-JW6) in the first round of PCR and specific primers (JW12-JEBL1) for the second round. RNA integrity was verified by amplifying 18S rRNA using a commercial Competimer system (Ambion, France) in each RT-PCR reaction.

To detect EBLV-1-specific neutralising antibodies in blood samples, a modified FAVN test was performed (Cliquet et al., 1998) with an EBLV-1 virus strain (ANSES, $\mathrm{N}^{\circ} 121411$ ) isolated in France (2000). Samples were tested in threefold dilutions on BHK-21 cells with a starting dilution of 1/27. Controls included uninfected BHK-21 cells, OIE positive dog serum, negative dog serum and back-titration of the specific EBLV-1 virus. Levels of virus-neutralising antibodies are expressed in $\log D_{50}$. The threshold of antibody detection was calculated by using the Spearman-Karber formula and set at $1.67 \log D_{50}$.

The $95 \%$ confidence intervals $(95 \% \mathrm{Cl}$ ) of seroprevalence data were calculated using free opensource R software, version 2.8.1 (R Development Core Team, 2004).

\section{Results}

\section{Presence of EBLV-1 antibodies (mFAVN test)}

From 2004 to 2009, of the 185 bat blood samples, 4 contained insufficient quantities to perform mFAVNt, 177 yielded readable mFAVNt results and 4 were not interpretable. 
108 Neutralising EBLV-1 antibodies were detected in 19 bats (range, $1.67-2.99 \log D_{50}$ ). Of these

109 antibody-positive bats, six species were identified: E. serotinus $(\mathrm{n}=7)$, Myotis myotis $(\mathrm{n}=5)$,

110 Myotis blythii $(\mathrm{n}=1)$, M. blythii or M. myotis $(\mathrm{n}=2)$, Miniopterus schreibersii $(\mathrm{n}=2)$, Barbastella 111 barbastellus $(n=1)$ and Rhinolophus ferrumequinum $(n=2)$. Antibodies to EBLV-1 were detected 112 in bats from seven sites, stretching from south-western to central France (Table 2). Infection 113 with EBLV-1a had already been reported in areas. Antibody-negative samples were recorded in 114 central France (sites 6 and 7) and also in north-eastern France (sites 1 to 5), north-western 115 France (site 8) and south-western France (sites 10, 15 and 16).

116 Of the 19 antibody-positive individuals, 13 were females and 6 were males. On the total bats 117 population, seroprevalence among females ( $n=13 ; 18.6 \%$ seroprevalence; $95 \% \mathrm{Cl}, 10.64-30.02)$ 118 was significantly higher $\left(\chi^{2}=6.13 ; P=0.013\right)$ than among males $(n=6 ; 5.6 \%$ seroprevalence; $95 \%$ $119 \mathrm{Cl}, 2.23-12.30)$.

121 Presence of infectious viruses (RTCIT) and viral RNA from oral swabs (hnRT-PCR)

122 All RTCIT samples ( $n=173$ ) were negative for infectious viruses (Table 2). The 308 collected 123 saliva samples were tested for the simultaneous presence of host 18S rRNA and viral EBLV-1 124 RNA. Host RNA was detected in $88 \%(n=271)$ of swabs; none of the tested samples were 125 positive for EBLV-1 RNA (Table 2).

\section{Discussion}

128 The purpose of the present study was to investigate the circulation of EBLV-1 among indigenous 129 bat species in France. This study is the first report of EBLV-1 neutralising antibodies in bats in

130 France (B. barbastellus, $E$. serotinus, $M$. blythii, $M$. myotis, $M$. schreibersii and $R$. 131 ferrumequinum). Our results are consistent with previous field studies in Europe.

132 Several European bat species have been already shown to be serologically positive: $M$. myotis, 133 M. schreibersii, R. ferrumequinum and Tadarida teniotis (Serra-Cobo et al., 2002). Antibodies 134 have previously been detected in E. serotinus (Freuling et al., 2009a; Perez-Jorda et al., 1995; 135 Vazquez-Moron et al., 2008a; Vazquez-Moron et al., 2008b) as well as in other species, such as 136 Plecotus sp., M. natterei (Klein et al., 2007) or, in southern Spain, E. isabellinus (Vazquez137 Moron et al., 2008b).

138 In contrast, some hundreds of serum samples from 17 other bat species have tested 139 serologically negative in Spain, Germany, Belgium (Freuling et al., 2009a) and in France. 140 Seroprevalence is low [00.5 to 3.8\%] in Daubenton's bats in the UK (Brookes et al., 2005) but in 141 Belgium no EBLV-2 antibodies have been detected in this species. The main techniques used in 142 Europe to determine the seroprevalence in bats are based on FAVNt, which directly measure 143 the antigen-specific neutralising antibody response. These techniques have been adapted for 
144 bat studies (in terms of screened viruses, sample dilutions and positivity thresholds). The

145 differences in levels of rabies-neutralising antibodies may be due to a lack of harmonization of

146 the serological technique (Cliquet et al., 1998; Freuling et al., 2009a) or to physiological stress in

147 bats that may change the immune response with respect to lyssaviruses (Messenger et al.,

148 2003). The level of detected antibodies by mFAVNt could be the result of serological cross-

149 reactivity (Wright et al., 2010) between Lyssavirus (EBLV-2, WCBV or an yet unknown

150 serologically Lyssavirus), even if the serological test has been adapted to EBLV-1. However, to

151 date and despite the reinforcement of bat rabies passive surveillance, no other rabies virus than

152 EBLV-1 was reported in France.

154 EBLV-1 antibodies in female bats are more frequent than in males, with respectively $18.6 \%$

$155[95 \% \mathrm{Cl}, 10.64-30.02]$ and $5.6 \%[95 \% \mathrm{Cl}, 2.23-12.30]$ of seroprevalence. This difference in 156 seroprevalence may arise from to the well-known gregarious behaviour of female bats. The 157 presence of antibodies in females suggests that virus transmission occurs within the breeding 158 colonies during social grooming, nursing or olfactory or lingual contact with body fluids. Adult 159 male serotines, known to inhabit maternity colonies, may also play a role in virus transmission 160 (Vos et al., 2007). Reproductive activity, also recently shown to be an important factor affecting 161 rabies seroprevalence, may also play a role in virus transmission (Turmelle et al. 2010). In this 162 study, males from only two bat species ( $M$. schreibersii and M. myotis) were shown to be 163 serologically positive. However, this observation must be interpreted with caution due to the 164 limited sample size for mFAVNt analysis. Further investigation is needed, particularly in species 165 that may contribute to the dispersal of EBLV-1. M. myotis has a large activity space, covering a 166 radius of about $25 \mathrm{~km}$ (Schober and Grimmberger, 1991) and the distance between their 167 summer and winter roosts varies between 20 and $253 \mathrm{~km}$. In M. schreibersii, seasonal migration 168 distances are greater than $350 \mathrm{~km}$ (Schober and Grimmberger, 1991) between Spain and 169 France (Serra-Cobo and Balcells, 1986; Serra-Cobo et al., 1998). Serotine bats are considered 170 to be sedentary and non-migratory, although distances of 10 to $45 \mathrm{~km}$ have been reported in 171 central Europe (Havekost, 1960), given their strong philopatry for hibernation and breeding 172 roosts.

174 The effect of lyssavirus infection in bat populations has still not been resolved and the presence 175 of rabies antibodies in bat sera is difficult to interpret. It is currently unknown whether antibody176 positive animals have ever been infectious and have recovered from a rabies infection or 177 whether the presence of antibodies is evidence of a peripheral infection prevented by the 178 immune response of the host (Constantine et al., 1968). Our study suggests that bats previously 179 exposed to EBLVs, have recovered from infection and have developed a neutralising antibody 180 response. This hypothesis is supported by recapture data on EBLV-1 in M. myotis species in 
181 Spain, indicating that there may be cycles of infection and persistent immunity (Amengual et al.,

182 2007). Detection of EBLV-1 antibodies in free-ranging bats probably demonstrates that bats

183 have been exposed to rabies virus antigens, reflecting immunity rather than a viral incubation

184 phase or ensuing illness (Shankar et al., 2004). The development of antibodies and subsequent

185 immunity to rabies may be attained via frequent exposure to small viral loads during social 186 contact among bats, through biting, scratching or grooming.

187 The presence of antibodies in six different bat species suggests that viruses are also transmitted 188 among bats, as previously reported in Europe and in the Americas (Constantine et al., 1968; 189 Serra-Cobo et al., 2002; Shankar et al., 2004; Smith et al., 2006; Turmelle et al., 2010). Bats 190 share their roosts primarily with conspecifics, but also with other bat species (serotine bats are 191 commonly observed with P. pipistrellus, M. myotis, Nyctalus noctula and Vespertilo murinus 192 offering many opportunities for interspecific virus transmission (Freuling et al., 2009a; Vos et al., 193 2007).

In the present study, all tested bats appeared to be "healthy" and none exhibited any obvious clinical signs of rabies. No viral RNA was detected in RT-PCRs performed on oral swabs during the study. These data suggest that the virus was not excreted by the bats at the time of sampling, as demonstrated in several experimental bat infections (Franka et al., 2008; Freuling et al., 2009b; Johnson et al., 2008) and other active surveys (Brookes et al., 2005; Harris et al., 2009; Kuzmin et al., 2008). In contrast to studies in Spain, we did not detect any viral RNA in oral swabs (Echevarria et al., 2001; Vazquez-Moron et al., 2008b). This difference may be due to temporal fluctuations in viral RNA, to insufficient amounts of viral RNA for detection by RTPCR or to the overall better apparent health status of all tested bats captured in flight. The results of the present study suggest that serologically positive bats are concentrated in south-western France, where EBLV-1a-infected bats are most frequently encountered, with the first case of EBLV-1a found in 2003. In contrast, EBLV-1b infections and antibodies in bats do not appear to have the same geographical distribution as EBLV-1a. Further studies will be undertaken to determine the detailed distribution of antibody-positive bats in France.

\section{Conclusion}

211 Continuing active and passive surveillance of bats will help increase knowledge of EBLV-1a and 212 b distribution and epidemiology in France. Furthermore, owing to the numerous serological 213 techniques used in European laboratories working on rabies, there is an urgent need to 214 standardise and harmonise the serological testing of bat rabies in free-ranging bats. 


\section{Acknowledgments}

We would like to thank the SFEPM (Société Française pour l'Etude et la Protection des Mammifères, Chiroptera group), for their effective collaboration in passive and active surveillance of bat rabies.

We gratefully acknowledge the proficient technical support provided by the serology team (Anouck Labadie and Laetitia Tribout) for serological testing, the diagnosis team (Alexandre Servat, Estelle Litaize, Josiane Ambert, and Valère Brogat) for rabies diagnosis, Mélanie Biarnais and Sébastien Kempff for PCR, the field unit (particularly Dr Franck Boué) and Dr Jacques Barrat.

We are also grateful to the Directorate General for Food (Direction Générale de l'Alimentation) of the French Ministry of Agriculture and to the French Ministry of the Environment.

\section{References}

Amengual, B., Bourhy, H., Lopez-Roig, M., Serra-Cobo, J., 2007. Temporal dynamics of European bat Lyssavirus type 1 and survival of Myotis myotis bats in natural colonies. PLoS ONE 2, e566.

Banyard, A.C., Johnson, N., Voller, K., Hicks, D., Nunez, A., Hartley, M., Fooks, A.R., 2009. Repeated detection of European bat lyssavirus type 2 in dead bats found at a single roost site in the UK. Arch. Virol. 154, 1847-1850.

Barrat, J., Barrat, M., Picard, M., Aubert, M., 1988. Diagnostic de la rage sur culture cellulaire. Comparaison des résultats de l'inoculation au neuroblastome murin et de l'inoculation à la souris. Comp. Immunol., Microbiol. Infect. Dis. 11, 207-214.

Bourhy, H., Kissi, B., Tordo, N., 1993. Molecular diversity of the Lyssavirus genus. Virology 194, 70-81.

Brookes, S.M., Aegerter, J.N., Smith, G.C., Healy, D.M., Jolliffe, T.A., Swift, S.M., Mackie, I.J., Pritchard, J.S., Racey, P.A., Moore, N.P., Fooks, A.R., 2005. European bat lyssavirus in Scottish bats. Emerg. Infect. Dis. 11, 572-578.

Carstens, E.B., 2010. Ratification vote on taxonomic proposals to the International Committee on Taxonomy of Viruses (2009). Arch. Virol. 155, 133-146.

Cliquet, F., Aubert, M., Sagne, L., 1998. Development of a fluorescent antibody virus neutralisation test (FAVN test) for the quantitation of rabies-neutralising antibody. $\mathrm{J}$. Immunol. Methods 212, 79-87.

Cliquet, F., Freuling, C., Smreczak, M., Van der Poel, W., Horton, D., Fooks, A., Robardet, E., Picard-Meyer, E., Müller, T., 2010. Development of harmonised schemes for monitoring and reporting of rabies in animals in the European Union. EFSA report, 1-60.

Constantine, D.G., Tierkel, E.S., Kleckner, M.D., Hawkins, D.M., 1968. Rabies in New Mexico cavern bats. Public Health Rep. 83, 303-316.

Dietz, C., Von Helversen, O. 2004. Illustrated identification key to the bats of Europe http://www.le-vespere.org/Ressources.php.

Echevarria, J.E., Avellon, A., Juste, J., Vera, M., Ibanez, C., 2001. Screening of active lyssavirus infection in wild bat populations by viral RNA detection on oropharyngeal swabs. J. Clin. Microbiol. 39, 3678-3683. 
Franka, R., Johnson, N., Muller, T., Vos, A., Neubert, L., Freuling, C., Rupprecht, C.E., Fooks, A.R., 2008. Susceptibility of North American big brown bats (Eptesicus fuscus) to infection with European bat lyssavirus type 1. J. Gen. Virol. 89, 1998-2010.

Freuling, C., Vos, A., Johnson, N., Fooks, A.R., Muller, T., 2009a. Bat rabies-a Gordian knot? Berl. Münch Tierärztl. Wochenschr. 122, 425-433.

Freuling, C., Vos, A., Johnson, N., Kaipf, I., Denzinger, A., Neubert, L., Mansfield, K., Hicks, D., Nunez, A., Tordo, N., Rupprecht, C.E., Fooks, A.R., Muller, T., 2009b. Experimental infection of serotine bats (Eptesicus serotinus) with European bat lyssavirus type 1a. J. Gen. Virol. 90, 2493-2502.

Harris, S.L., Aegerter, J.N., Brookes, S.M., McElhinney, L.M., Jones, G., Smith, G.C., Fooks, A.R., 2009. Targeted surveillance for European bat lyssaviruses in English bats (200306). J. Wildl. Dis. 45, 1030-1041.

Havekost, H., 1960. Die Beringung der Breitfluggelfledermaus (Eptesicus serotinus Schreber) im Oldenburger Land. . Bonn. Zool. Beitr. 11, 222-233.

Johnson, N., Vos, A., Neubert, L., Freuling, C., Mansfield, K.L., Kaipf, I., Denzinger, A., Hicks, D., Nunez, A., Franka, R., Rupprecht, C.E., Muller, T., Fooks, A.R., 2008. Experimental study of European bat lyssavirus type-2 infection in Daubenton's bats (Myotis daubentonii). J. Gen. Virol. 89, 2662-2672.

Klein, F., Audry, L., Fairon, J., Bourhy, H., 2007. Fisrt clue of circulation of Lyssaviruses in bat populations. Abstract book of the Second Symposium of the Belgian Wildlife Disease Society, Brussels, 45.

Kuzmin, I.V., Niezgoda, M., Franka, R., Agwanda, B., Markotter, W., Beagley, J.C., Urazova, O.Y., Breiman, R.F., Rupprecht, C.E., 2008. Possible emergence of West Caucasian bat virus in Africa. Emerg. Infect. Dis. 14, 1887-1889.

Med Vet Net Working Group, 2005. Passive and Active surveillance of bat Lyssavirus infections. Rabies Bull. Europe 29, 5-6.

Messenger, S.L., Rupprecht, C.E., Smith, J.S., 2003. Bats, emerging virus infections, and the rabies paradigm, In: Kunz T, F.M.E. (Ed.), Bat ecology. Univ. Chicago Press, Chicago, pp. 622-679.

Moutou, F., Dufour, B., Hattenberger, A.M. 2003. Rapport sur la rage des chiroptères en France métropolitaine. Rapport AFSSA, $70 \mathrm{p}$.

Muller, T., Johnson, N., Freuling, C.M., Fooks, A.R., Selhorst, T., Vos, A., 2007. Epidemiology of bat rabies in Germany. Arch. Virol. 152, 273-288.

Perez-Jorda, J.L., Ibanez, C., Munoz-Cervera, M., Tellez, A., 1995. Lyssavirus in Eptesicus serotinus (Chiroptera: Vespertilionidae). J. Wildl. Dis. 31, 372-377.

Picard-Meyer, E., Bruyere, V., Barrat, J., Tissot, E., Barrat, M.J., Cliquet, F., 2004. Development of a hemi-nested RT-PCR method for the specific determination of European Bat Lyssavirus 1. Comparison with other rabies diagnostic methods. Vaccine 22, 1921-1929.

R Development Core Team, 2004. R: A language and environment for statistical computing R. F. f. S. Computing, Vienna, Austria.

Sabeta, C.T., Markotter, W., Mohale, D.K., Shumba, W., Wandeler, A.I., Nel, L.H., 2007. Mokola virus in domestic mammals, South Africa. Emerg. Infect. Dis. 13, 1371-1373.

Schober, W., Grimmberger, E., 1991. Guide des chauves-souris d'Europe. Delachaux et Niestlé, Lausanne, $225 \mathrm{p}$.

Selimov, M.A., Smekhov, A.M., Antonova, L.A., Shablovskaya, E.A., King, A.A., Kulikova, L.G., 1991. New strains of rabies-related viruses isolated from bats in the Ukraine. Acta Virol. 35, 226-231.

Serra-Cobo, J., Amengual, B., Abellan, C., Bourhy, H., 2002. European bat lyssavirus infection in Spanish bat populations. Emerg. Infect. Dis. 8, 413-420. 
Serra-Cobo, J., Balcells, E., 1986. Mise à jour des résultats des campagnes de baguage de Miniopterus schreibersii dans le N.E. espagnol et le S.E. français. In: IXème Colloque Francophone de Mammalogie, "Les Chiroptères", Rouen 19-20 octobre. S.F.E.P.M., Paris, 85-98.

Serra-Cobo, J., Sanz-Trullén, V., Martínez-Rica, J.P., 1998. Migratory movements of Miniopterus schreibersii in the north-east Spain. Acta Theriol. 43, 271-283.

Shankar, V., Bowen, R.A., Davis, A.D., Rupprecht, C.E., O'Shea T, J., 2004. Rabies in a captive colony of big brown bats (Eptesicus fuscus). J. Wildl. Dis. 40, 403-413.

Smith, G.C., Brookes, S.M., Harris, S.L., Aegerter, J.N., Jones, G., Fooks, A.R., 2006. EBLV-2 prevalence in the United Kingdom as determined by surveillance testing. In: Dodet, B., Schudel, A., Pastoret, P.P., Lombard, M. (Eds.), First international conference on rabies in Europe. Karger Ed., Basel, 125, pp. 265-271.

Turmelle, A.S., Allen, L.C., Jackson, F.R., Kunz, T.H., Rupprecht, C.E., McCracken, G.F., 2010. Ecology of rabies virus exposure in colonies of Brazilian free-tailed bats (Tadarida brasiliensis) at natural and man-made roosts in Texas. Vector Borne Zoon. Dis. 10, 165175.

Van der Poel, W.H., Van der Heide, R., Van Amerongen, G., Van Keulen, L.J., Wellenberg, G.J., Bourhy, H., Schaftenaar, W., Groen, J., Osterhaus, A.D., 2000. Characterisation of a recently isolated lyssavirus in frugivorous zoo bats. Arch. Virol. 145, 1919-1931.

Vazquez-Moron, S., Juste, J., Ibanez, C., Aznar, C., Ruiz-Villamor, E., Echevarria, J.E., 2008a. Asymptomatic rhabdovirus infection in meridonial serotine bats (Eptesicus isabellinus) from Spain. In: Dodet, B., Fooks, A.R., Muller, T., Tordo, N. (Eds.), Towards the elimination of rabies in Eurasia. Karger Ed., Basel, 131, pp. 311-316.

Vazquez-Moron, S., Juste, J., Ibanez, C., Ruiz-Villamor, E., Avellon, A., Vera, M., Echevarria, J.E., 2008b. Endemic circulation of European bat lyssavirus type 1 in serotine bats, Spain. Emerg. Infect. Dis. 14, 1263-1266.

Vos, A., Kaipf, I., Denzinger, A., Fooks, A.R., Johnson, N., Müller, T., 2007. European bat lyssaviruses-an ecological enigma. Acta Chiropt. 9, 283-296.

World Health Organisation, 2008. Rabies. Fact Sheet $\mathrm{N}^{\circ} 99$.

Wright, E., Hayman, D.T., Vaughan, A., Temperton, N.J., Wood, J.L., Cunningham, A.A., SuuIre, R., Weiss, R.A., Fooks, A.R., 2010. Virus neutralising activity of African fruit bat (Eidolon helvum) sera against emerging lyssaviruses. Virology 408, 183-189.

Figure 1A: Location of bat sampling sites in France. Circles indicate the location (number code given in Table 1) and circle size is proportional to the number of bats sampled.

Figure 1B. Geographical distribution of the 19 serologically positive bats with the localisation of the 51 EBLV-1-infected serotine bats diagnosed during passive surveillance. In all bats sampled during active surveillance, all saliva samples were negative for EBLV-1 RNA using the hnRTPCR technique. 
Table 1: Number of saliva (blood) samples collected, by bat species and by study site.

\begin{tabular}{|c|c|c|c|c|c|c|c|c|c|c|c|c|c|c|c|c|c|c|}
\hline Rouian & & rth-e & asterr & Franc & & & Eentr & & $\begin{array}{l}\text { North- } \\
\text { wester } \\
\text { n } \\
\text { Franc }\end{array}$ & & & & uth-we & sternf & Fran & & & \\
\hline Species\Site no. & 1 & 2 & 3 & 4 & 5 & 6 & 7 & $\begin{array}{l}9 \\
+\end{array}$ & 8 & 10 & $\begin{array}{c}11 \\
+\end{array}$ & $\begin{array}{c}12 \\
+\end{array}$ & $\begin{array}{c}13 \\
+\end{array}$ & $\begin{array}{c}14 \\
+\end{array}$ & 15 & 16 & $\begin{array}{c}17 \\
+\end{array}$ & $\begin{array}{c}18 \\
+\end{array}$ \\
\hline R. euryale & & & & & & & & & & $\begin{array}{c}3 \\
(0)\end{array}$ & & & $\begin{array}{c}1 \\
(0)\end{array}$ & & & & $\begin{array}{c}1 \\
(0)\end{array}$ & \\
\hline R. ferrumequinum & & & & & & & & & & & $\begin{array}{c}3 \\
(3) \\
\end{array}$ & $\begin{array}{c}1 \\
(0) \\
\end{array}$ & & $\begin{array}{c}2 \\
(1) \\
\end{array}$ & $\begin{array}{c}2 \\
(2)\end{array}$ & $\begin{array}{c}2 \\
(2)\end{array}$ & $\begin{array}{c}9 \\
(2)\end{array}$ & $\begin{array}{c}2 \\
(2)\end{array}$ \\
\hline R. hipposideros & & & $\begin{array}{c}7 \\
(0)\end{array}$ & $\begin{array}{c}3 \\
(0)\end{array}$ & & & & & & & & & & $\begin{array}{c}1 \\
1 \\
(1)\end{array}$ & +1 & & & \\
\hline B. barbastellus & & & $\begin{array}{c}2 \\
(0)\end{array}$ & & & & & & & & & & & $\begin{array}{c}1 \\
\text { (1) }\end{array}$ & $\begin{array}{c}1 \\
(1)\end{array}$ & & $\begin{array}{c}3 \\
(0)\end{array}$ & \\
\hline E. serotinus & & & & & & $\begin{array}{l}11 \\
(0)\end{array}$ & $\begin{array}{l}33 \\
(0)\end{array}$ & $\begin{array}{l}12 \\
(12)\end{array}$ & & & $\begin{array}{c}2 \\
(2)\end{array}$ & $\begin{array}{c}7 \\
(7)\end{array}$ & & $\begin{array}{c}1 \\
(1)\end{array}$ & $\begin{array}{c}1 \\
(1)\end{array}$ & & $\begin{array}{c}5 \\
(5)\end{array}$ & \\
\hline M. alcathoe & & $\begin{array}{c}2 \\
(0)\end{array}$ & & & & & & & & & & & & & & & & \\
\hline M. bechsteinii & $\begin{array}{c}2 \\
(0)\end{array}$ & & & $1(0)$ & $\begin{array}{c}3 \\
(3) \\
\end{array}$ & & & & & & & 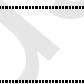 & & & & & $\begin{array}{c}1 \\
(0)\end{array}$ & \\
\hline M. blythii & & & & & & & & & & & $\begin{array}{c}3 \\
(3)\end{array}$ & $\begin{array}{c}2 \\
(2)\end{array}$ & & & & & & \\
\hline M. daubentonii & $\begin{array}{c}1 \\
(0)\end{array}$ & & & & $\begin{array}{c}5 \\
(5)\end{array}$ & & & & & & & $\begin{array}{c}2 \\
(2)\end{array}$ & & $\begin{array}{c}1 \\
(0)\end{array}$ & $\begin{array}{c}2 \\
(2)\end{array}$ & $\begin{array}{c}7 \\
(3)\end{array}$ & $\begin{array}{c}8 \\
(5)\end{array}$ & $\begin{array}{c}1 \\
(1)\end{array}$ \\
\hline M. emarginatus & $\begin{array}{c}8 \\
(0)\end{array}$ & & & & $\begin{array}{c}18 \\
(16)\end{array}$ & & & & & & & & & & & & $\begin{array}{c}1 \\
(0)\end{array}$ & \\
\hline M. myotis & & & $\begin{array}{c}1 \\
(1)\end{array}$ & & $\begin{array}{c}8 \\
(8)\end{array}$ & & & & & & $\begin{array}{c}1 \\
(1)\end{array}$ & $\begin{array}{c}17 \\
(17) \\
\end{array}$ & & $\begin{array}{c}4 \\
(4) \\
\end{array}$ & & & $\begin{array}{c}9 \\
(8)\end{array}$ & \\
\hline M. myotis/blythii & & & & & & & & & $\nabla$ & & $\begin{array}{c}2 \\
(2)\end{array}$ & $\begin{array}{c}7 \\
(7)\end{array}$ & & & & $\begin{array}{c}1 \\
(1)\end{array}$ & & $\begin{array}{c}1 \\
\text { (1) }\end{array}$ \\
\hline M. mystacinus & $\begin{array}{c}1 \\
(0) \\
\end{array}$ & & & & $\begin{array}{c}0 \\
(0) \\
\end{array}$ & & & $\nabla$ & $\begin{array}{c}2 \\
(2)\end{array}$ & & & & & & & & & \\
\hline M. nattereri & $\begin{array}{c}2 \\
(0)\end{array}$ & & $3(0)$ & & $\begin{array}{c}3 \\
(3)\end{array}$ & & & & & & & & & & & & $\begin{array}{c}2 \\
(0)\end{array}$ & \\
\hline M. schreibersii & & & & & & & 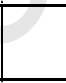 & & & & & & $\begin{array}{c}14 \\
(14)\end{array}$ & $\begin{array}{c}3 \\
(3)\end{array}$ & & & $\begin{array}{c}1 \\
(0)\end{array}$ & \\
\hline P. auritus & $\begin{array}{c}1 \\
(0) \\
\end{array}$ & & & $1(0)$ & $\begin{array}{c}1 \\
(1)\end{array}$ & & & & $\begin{array}{c}4 \\
(4)\end{array}$ & & & & & & & & $\begin{array}{c}1 \\
(0)\end{array}$ & \\
\hline P. austriacus & & & & & & & & & $\begin{array}{c}15 \\
(12)\end{array}$ & & & & & & $\begin{array}{c}1 \\
(1)\end{array}$ & & & \\
\hline P. kuhlii & & & & & & & & & $\begin{array}{c}1 \\
(1)\end{array}$ & & & & & & & & & \\
\hline P. pipistrellus & & & & $P$ & $\begin{array}{c}1 \\
(0)\end{array}$ & & & & $\begin{array}{c}9 \\
(8)\end{array}$ & & & & & & $\begin{array}{c}6 \\
(1)\end{array}$ & & $\begin{array}{c}1 \\
(0)\end{array}$ & \\
\hline $\begin{array}{l}\text { Total number of } \\
\text { saliva samples } \\
\text { (blood) }\end{array}$ & $\begin{array}{l}15 \\
(0)\end{array}$ & $\begin{array}{c}2 \\
(0)\end{array}$ & $\begin{array}{l}13 \\
(1)\end{array}$ & $\begin{array}{l}5 \\
(0)\end{array}$ & $\begin{array}{l}39 \\
(36)\end{array}$ & $\begin{array}{l}11 \\
(0)\end{array}$ & $\begin{array}{l}33 \\
(0)\end{array}$ & $\begin{array}{l}12 \\
(12)\end{array}$ & \begin{tabular}{|l}
31 \\
$(27)$
\end{tabular} & $\begin{array}{l}3 \\
(0)\end{array}$ & $\begin{array}{l}11 \\
(11)\end{array}$ & $\begin{array}{l}36 \\
(35)\end{array}$ & $\begin{array}{l}15 \\
(14)\end{array}$ & $\begin{array}{l}13 \\
(11)\end{array}$ & $\begin{array}{l}13 \\
(8)\end{array}$ & $\begin{array}{l}10 \\
(6)\end{array}$ & $\begin{array}{l}42 \\
(20)\end{array}$ & $\begin{array}{l}4 \\
(4)\end{array}$ \\
\hline
\end{tabular}

3 †: sites positive for EBLV-1 antibodies. Values give the number of collected saliva samples; the number of collected 4 blood samples for mFAVN test is given in parentheses.

5 The municipalities of study sites numbered 1 to 18 are as follows: Tincry (1), Montiers sur Saulx (2), Neufchateau-

6 Rebeuville (3), Neufchateau-Landaville (4), Chamarandes-Choignes (5), Saint Loup des Chaumes (6), Saint Amand

7 Montrond (7), Fontenay le Comte (8), Guéret (9), Lafage (10), Rocamadour (11), Gasques (12), Dunes (13), Loze

8 (14), Feneyrols (15), Roussayrolles (16), Penne $1 \& 2$ (17), Saint Antonin Noble Val (18). 
1 Table 2: Results of laboratory investigations on the presence of infectious rabies virus (RTCIT), 2 viral RNA (hnRT-PCR) and the detection of EBLV-1 antibodies in bats (mFAVNt).

3

\begin{tabular}{|c|c|c|c|c|c|c|c|c|}
\hline \multirow[b]{2}{*}{ Species } & \multirow[b]{2}{*}{ RTCIT } & \multirow[b]{2}{*}{$\begin{array}{c}\text { hnRT- } \\
\text { PCR }\end{array}$} & \multicolumn{6}{|c|}{ Antibody detection in bats (mFAVNt) } \\
\hline & & & $\begin{array}{c}\text { mFAVN } \\
\text { test }\end{array}$ & $\begin{array}{c}\text { \% with } \\
\text { antibody }\end{array}$ & $95 \% \mathrm{Cl}$ & $\mathrm{F}$ & $\mathrm{M}$ & Study Sites \\
\hline R. euryale & $0(4)$ & $0(5)$ & 1 & 1 & I & $0(0)$ & $0(0)$ & \\
\hline R. hipposideros & $0(11)$ & $0(11)$ & $0(1)$ & 0 & {$[0-95.5]$} & $0(1)$ & $0(0)$ & \\
\hline R. ferrumequinum & $0(11)$ & $0(21)$ & $1(10)$ & 10 & {$[0.5-45.9]$} & $1(5)$ & $0(5)$ & 18 \\
\hline B. barbastellus & $0(6)$ & $0(7)$ & $1(2)$ & 50 & {$[9.5-90.5]$} & $1(2)$ & $0(0)$ & 14 \\
\hline E. serotinus & $0(18)$ & $0(72)$ & $7(28)$ & 25 & {$[11.4-45.2]$} & $7(19)$ & $0(9)$ & $9,11,12$ \\
\hline M. alcathoe & / & $0(1)$ & I & / & 1 & $0(0)$ & $0(0)$ & \\
\hline M. bechsteini & $0(7)$ & $0(5)$ & $0(3)$ & 0 & {$[0-69.0]$} & $0(0)$ & $0(3)$ & \\
\hline M. blythii & I & $0(5)$ & $1(5)$ & 20 & {$[1.0-70.1]$} & $1(2)$ & $0(3)$ & 11 \\
\hline M. daubentonii & $0(15)$ & $0(22)$ & $0(17)$ & 0 & {$[0-22.9]$} & $0(5)$ & $0(12)$ & \\
\hline M. emarginatus & $0(27)$ & $0(10)$ & $0(16)$ & 0 & {$[0-24.1]$} & $0(1)$ & $0(15)$ & \\
\hline M. myotis & $0(22)$ & $0(36)$ & $5(37)$ & 13.5 & {$[5.1-29.6]$} & $2(19)$ & $3(18)$ & $12,14,17$ \\
\hline M. myotis/blythii & I & $0(11)$ & $2(11)$ & 18.2 & {$[3.2-52.2]$} & $1(4)$ & $1(7)$ & 12,18 \\
\hline M. mystacinus & $0(3)$ & $0(3)$ & $0(2)$ & 0 & {$[0-80.2]$} & $0(0)$ & $0(2)$ & \\
\hline M. nattereri & $0(10)$ & $0(7)$ & $0(3)$ & 0 & {$[0-60.9]$} & $0(2)$ & $0(1)$ & \\
\hline M. schreibersii & $0(4)$ & $0(18)$ & $2(17)$ & 11.8 & {$[2.1-37.7]$} & $0(6)$ & $2(11)$ & 13,14 \\
\hline$P$. auritus & $0(8)$ & $0(7)$ & $0(5)$ & 0 & {$[0-53.7]$} & $0(0)$ & $0(5)$ & \\
\hline P. austriacus & $0(15)$ & $0(15)$ & $0(13)$ & 0 & [0- 28.3] & $0(2)$ & $0(11)$ & \\
\hline P. kuhli & $0(1)$ & 1 & $0(1)$ & 0 & {$[0-95.5]$} & $0(0)$ & $0(1)$ & \\
\hline P. pipistrellus & $0(11)$ & $0(15)$ & $0(6)$ & 0 & {$[0-48.3]$} & $0(2)$ & $0(4)$ & \\
\hline Total & $0 / 173$ & $0 / 271$ & $19 / 177$ & 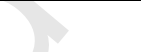 & & $13(70)$ & $6(107)$ & \\
\hline
\end{tabular}

4 Values correspond to the number of positive samples using the RTCIT, hnRT-PCR or mFAVN

5 test; the number given in parentheses gives the total number of tested samples.

6 Abbreviations: $\mathrm{Cl}$ : confidence interval; F: female; M: male. 


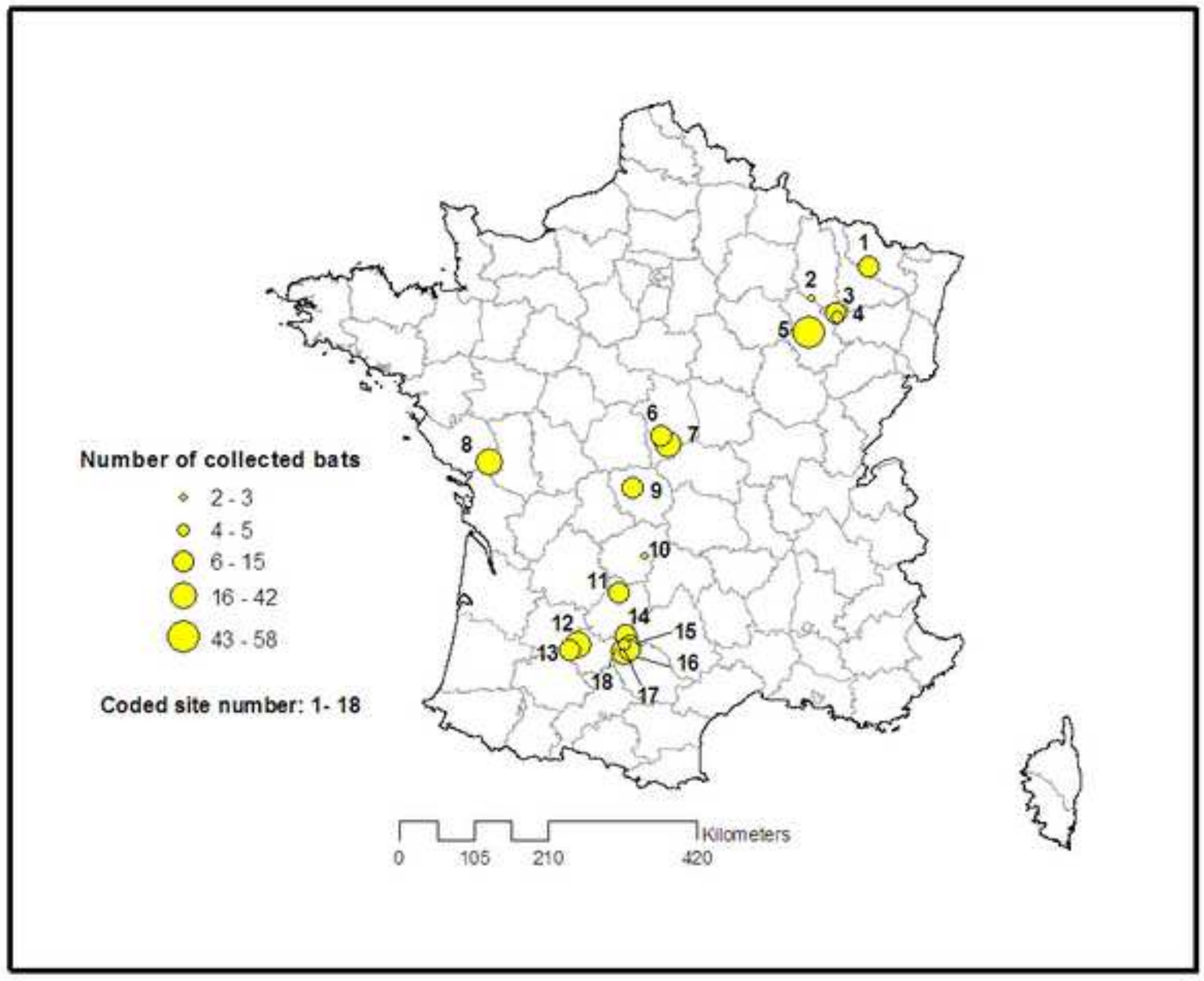

rage 12 or 13 


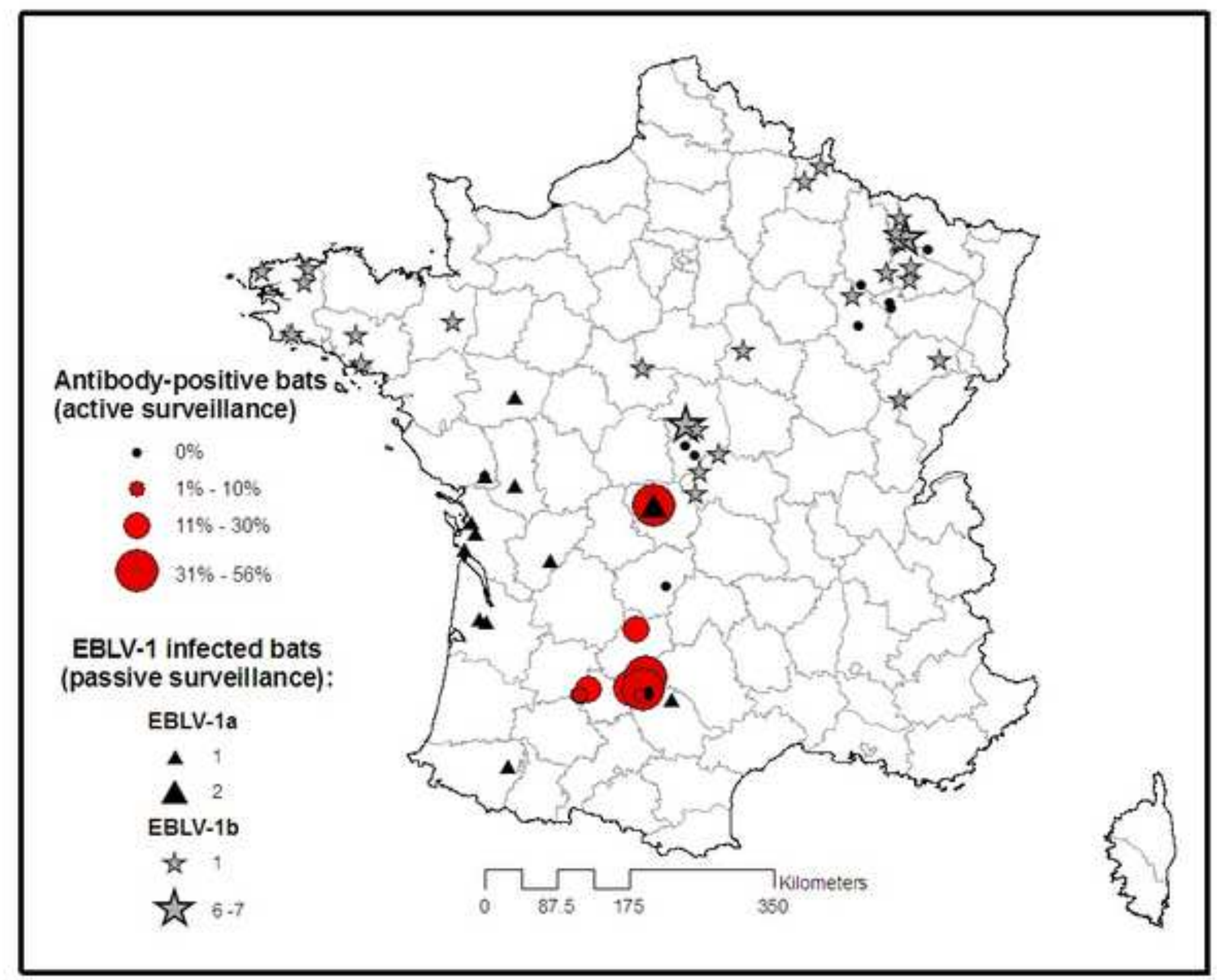

